\title{
On the meat scavenging behavior of House Sparrows (Passer domesticus)
}

\author{
Ian MacGregor-Fors, ${ }^{1 *}$ Michelle García-Arroyo, ${ }^{1}$ Oscar H. Marín-Gómez, ${ }^{1}$ and Javier Quesada ${ }^{2}$
}

ABSTRACT-Behavioral plasticity can drive feeding innovations, a frequent trait of urban exploiter species. The House Sparrow (Passer domesticus) is a widespread and abundant urban dweller whose success has often been related to its dietary breadth. Although both formal and informal sources (e.g., internet videos, news, and blogs) have shown meat scavenging behaviors of this sparrow, it has been overlooked in the literature. While it is recognized that this sparrow has a diverse diet in urban settings, quantitative sources report only 3 types of foods (i.e., seeds, plant origin, and invertebrates). Our field observation of a female House Sparrow feeding on a chicken "drumstick" (presumably fibula/tibia) leftover at a greenspace of Manhattan (i.e., High Line), USA, adds to the available formal and informal information regarding the opportunistic scavenging of dressed and cooked meat by these sparrows when available. Thus, our observation adds to the feeding plasticity knowledge of this urban-related invasive bird and suggests the importance of the role of pedestrians in molding

${ }^{1}$ Red de Ambiente y Sustentabilidad, Instituto de Ecología, A.C. (INECOL), El Haya, Xalapa, Veracruz, Mexico

${ }^{2}$ Departament de Vertebrats, Museu de Ciències Naturals de Barcelona, Barcelona, Catalonia, Spain

* Corresponding author: ian.macgregor@inecol.mx, macgregor.ian@gmail.com
House Sparrow diet. Received 6 May 2019. Accepted 4 December 2019.

Key words: meat, novel food resources, scavenger, urban ecology, urban exploiter species

\section{Sobre el comportamiento carroñero del gorrión doméstico (Passer domesticus)}

RESUMEN (Spanish) - La plasticidad conductual es un factor que puede impulsar las innovaciones alimenticias, un rasgo frecuente de las especies explotadoras urbanas. El gorrión doméstico (Passer domesticus) es una especie muy prolifera en zonas urbanas, cuyo éxito se ha relacionado con su amplitud de dieta. Aunque existe evidencia formal e informal (e.g., videos, noticias y blogs) que muestra el comportamiento carroñero de este gorrión, ésta información se ha pasado por alto en la literatura. Si bien se reconoce que éste gorrión tiene una dieta amplia en entornos urbanos, la información cuantitativa sobre su alimentación únicamente incluye 3 tipos de alimentos (i.e., semillas, origen vegetal e invertebrados). En esta nota reportamos a una hembra de gorrión doméstico que se alimentaba de un sobrante de "pierna" de pollo (presumiblemente peroné / tibia) en un área verde de Manhattan (i.e., High Line), EE. UU. Nuestra observación se suma a la información formal e informal disponible sobre el comportamiento carroñero por parte de estos gorriones cuando esta 
disponible. Por lo tanto, nuestra observación contribuye al conocimiento sobre la plasticidad alimentaria de esta ave invasora relacionada con la urbanización y sugiere la importancia del papel de los peatones en la dieta del gorrión doméstico.

Palabras clave: carne, recursos alimenticios novedosos, carroñero, ecología urbana, especies explotadoras urbanas

Global assessments of urban avifaunas have identified several widespread generalist species that tend to have large urban populations, of which the following head the list: Rock Pigeon (Columba livia), House Sparrow (Passer domesticus), European Starling (Sturnus vulgaris), and Eurasian Collared-Dove (Streptopelia decaocto) (Aronson et al. 2014, Sol et al. 2014). Among the aforementioned species, all of which have broad generalist diets, Rock Pigeon and Eurasian Collared-Dove are mostly granivorous, and European Starling and House Sparrow are known for their dietary breadth. In particular, the House Sparrow has been studied for decades due to its impressive plasticity and invasive range-expanding capacity in several regions of the world (Anderson 2006). The invasion success of this sparrow as an urban exploiter species has been mainly attributed to some of its natural history traits, with its generalist diet playing a crucial role (Gavett and Wakeley 1986, Anderson 2006).

Although the House Sparrow is perceived as being an omnivore due to its dietary breadth, it has been described as a specialized granivore (Anderson 2006). Empirical studies have shown that their annual diet in non-urban areas can be comprised by up to $97 \%$ plant material, mainly grains (Kalmbach 1940). Important temporal variability on its diet has been also recorded, with plant material peaking between late autumn and early winter, and animal sources (mostly beetles) occurring in higher numbers during the breeding season (Kalmbach 1940, Hammer 1948).

However, its urban diet has shown to be impressively broad and different to that of nonurban areas. As Gavett and Wakeley (1986) showed more than 3 decades ago, House Sparrows rely on more food sources in urban areas when contrasted with non-urban ones. Thus, it is not surprising that studies have added a long list of components that comprise this species' urban diet, including seeds (both wild and commercial), fruits, nectar, plant parts (e.g., leaves, flowers), arthropods, frogs, mollusks, crustaceans, lizards, mice, and human litter (Gavett and Wakeley 1986, Anderson 2006, Summers-Smith et al. 2018). Although information is scarce in the literature regarding the type of litter and the consumption of meat by House Sparrows (e.g., Anderson 2006, Karthick et al. 2017, Summers-Smith et al. 2018), there is available informal evidence that reports its meat-scavenging behavior (e.g., internet blogs, news, and videos; Sukonkin 2009, Johnson 2016; Table 1).

Based on all of the above, it is evident that summarizing the diet of House Sparrows is not an easy task. Actually, sources such as EltonTraits 1.0 (Willman et al. 2014), the main quantitative foraging data set for the birds of the world, only considers this sparrow to include 3 food items as part of its diet: seeds $(60 \%)$, plant origin (not fruit, seed, or nectar; 30\%), and invertebrates $(10 \%)$. Although this source includes "scavenger" (i.e., garbage, offal, carcass, and carrion) and "vertebrate" (i.e., general or unknown) food items, there is no consideration of them as part of this sparrow's diet.

As it is evident that meat consumption by House Sparrows is shallowly mentioned, but largely overlooked in the literature, we provide here evidence and gather information on the scavenging of dressed and cooked meat by this urban-related bird species. By reporting an observation of a House Sparrow consuming meat from a discarded chicken "drumstick" (presumably fibula/tibia) in a New York City, USA, greenspace, we add to the knowledge that this species consumes meat as part of human leftovers and could include this item in its diet.

On the morning (1030 h EST) of 23 March 2017, IM-F spotted a female House Sparrow feeding on a chicken "drumstick" leftover located at a green strip of the High Line, an urban greenspace of Manhattan, New York City $\left(40^{\circ} 44^{\prime} 36^{\prime \prime} \mathrm{N}, 74^{\circ} 00^{\prime} 24.9^{\prime \prime} \mathrm{W} ; \sim 3 \mathrm{~m}\right.$ a.s.1.) (Fig. 1). This single female was recorded feeding on the chicken leftover for 3-5 min, while flying to the branches of a leafless shrub under which the "drumstick" was thrown. It is notable that the weather was still cold $\left(1{ }^{\circ} \mathrm{C}\right)$ and snowbanks with considerable depth were still on site given snowfall that occurred several days before the observation. The female sparrow boldly allowed IM-F to 
Table 1. Informal sources evidencing scavenging meat behaviors of House Sparrows (Passer domesticus).

\begin{tabular}{llll}
\hline \multicolumn{1}{c}{ Food } & Site & Type of source & URL \\
\hline Red meat & Germany & Video & https://www.youtube.com/watch?v=MKq10G0FPJk \\
Chicken meat & Albany & Video & https://www.youtube.com/watch?v=PI7M5UHaEJc \\
\hline
\end{tabular}

witness the feeding activity, with photographs and video footage being taken from less than $2 \mathrm{~m}$.

Besides well-known passerines that often feed on animal carcasses (e.g., Common Raven [Corvus corax], shrikes [Lanius spp.], grackles [Quiscalus spp.]), the scavenging consumption of both dressed and cooked meat by non-raptors has been recorded in several bird species, such as tits (Perrins and Cramp 1998, Selva et al. 2005) and lorikeets (Gillanders et al. 2017); yet this is generally an uncommon behavior. This feeding strategy has been closely related to human commensal species and/or those that benefit from living in human-dominated ecosystems (Lancaster 2005, Lefebvre et al. 2016, Porter and Behl 2016, Karthick et al. 2017). Although House Sparrows are known to increase their animal-protein consumption, mostly arthropods, during the breeding season (Anderson 2006), our field observation-together with additional formal and informal information-provides evidence of the opportunistic scavenging of dressed and cooked meat when available.

It has been recently proposed that scavenging meat by the House Sparrow could be associated with protein requirements by nestlings during the breeding season (Karthick et al. 2017). Also, meat consumption could be associated with severe

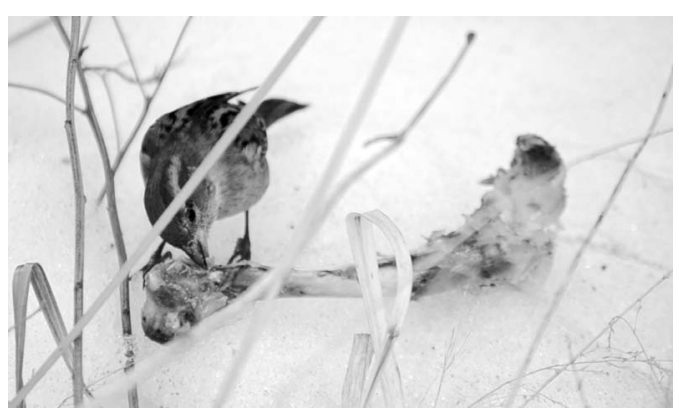

Figure 1. Female House Sparrow (Passer domesticus) feeding on a chicken "drumstick" (presumably fibula/tibia) in a green strip of the High Line, an urban greenspace of Manhattan, New York City, USA (photo: Ian MacGregorFors). weather conditions that tend to reduce the availability of main feeding resources, such as seeds and arthropods (Selva et al. 2005, Porter and Behl 2016). However, studies related to depleted diet consumption in European sparrows with decreasing populations do not explicitly report the consumption of meat (Vincent 2005).

Our observation adds to the feeding plasticity knowledge of this urban-related invasive bird, also suggesting that street litter, intentionally and unintentionally disposed of by pedestrians, can partially mold their diet (see Bower 1999 for the relationship between House Sparrow diet and human-supplied food). This is important to consider in the light of previous studies showing not only tolerance to humans, but even positive relationships between their numbers and pedestrian activity (FernándezJuricic 2001, MacGregor-Fors et al. 2010, 2017). Although there have been great efforts to compile lists and broad databases of species attributes (e.g., body size, diet, foraging strata; Wilman et al. 2014), we consider incidental observations like the one presented here valuable, as these may provide useful information not only for our knowledge but for consideration in decision making (e.g., prevention and control of invasive species).

\section{Acknowledgments}

We are deeply thankful to PJ Yeh, PS Warren, and L-B Vázquez for their comments and suggestions, which enhanced the clarity and quality of our contribution. IM-F thanks The Urban Biodiversity Research Coordination Network (UrBioNet) for the invitation to participate on the "Patterns, Drivers, and Traits" Workgroup, which led to the central observation of this study (NSF RCN: DEB-135467/ 1355151). OHM-G and MG-A acknowledge the scholarship and financial support provided by the National Council of Science and Technology (CONACYT 704916 and 700755, respectively), as well as the Doctoral Program of the Instituto de Ecología, A.C. (INECOL, Xalapa).

\section{Literature cited}

Anderson TR. 2006. Biology of the ubiquitous House Sparrow: From genes to populations. New York (NY): Oxford University Press. 
Aronson MFJ, La Sorte FA, Nilon CH, Katti M, Goddard MA, et al. 2014. A global analysis of the impacts of urbanization on bird and plant diversity reveals key anthropogenic drivers. Proceedings of the Royal Society B: Biological Sciences 281:20133330.

Bower S. 1999. Fortpflanzungsaktivität, Habitatnutzung und Populationsstruktur eines Schwarms von Haussperlingen (Passer $d$. domesticus) in Hamburger Stadtgebeit [Reproductive activity, habitat use and population structure of a flock of House Sparrows (Passer $d$. domesticus) in Hamburg's urban area]. Hamburger avifaunistische Beiträge 30:90-129.

Fernández-Juricic E. 2001. Avian spatial segregation at edges and interiors of urban parks in Madrid, Spain. Biodiversity and Conservation 10:1303-1316.

Gavett AP, Wakeley JS. 1986. Diets of House Sparrows in urban and rural habitats. Wilson Bulletin 98:137-144.

Gillanders R, Awasthy M, Jones DN. 2017. Extreme dietary switching: Widespread consumption of meat by Rainbow Lorikeets at garden bird feeders in Australia. Corella 41:32.

Hammer M. 1948. Investigations on the feeding-habits of the House-Sparrow (Passer domesticus) and the TreeSparrow (Passer montanus). Danish Review of Game Biology 17:1-59.

Johnson P. 2016. Watch: 17 birds found eating packaged meat in Chicopee Walmart. MASSLIVE [cited 3 March 2018]. https://www.masslive.com/news/2015/12/ meat-eating_birds_bother_chico.html

Kalmbach ER. 1940. Economic status of the English Sparrow in the United States. U.S. Department of Agriculture Bulletin 711:1-66.

Karthick S, Ramakrishnan B, Samson A, Santhoshkumar P. 2017. House Sparrows Passer domesticus feeding on dressed meat. Indian BIRDS 13:56.

Lancaster B. 2005. Blue Chaffinch eating meat. British Birds 98:435.

Lefebvre L, Ducatez S, Audet J-N. 2016. Feeding innovations in a nested phylogeny of Neotropical passerines. Philosophical Transactions of The Royal Society B: Biological Sciences 371:20150188.
MacGregor-Fors I, Morales-Pérez L, Quesada J, Schondube JE. 2010. Relationship between the presence of House Sparrows (Passer domesticus) and Neotropical bird community structure and diversity. Biological Invasions 12:87-96.

MacGregor-Fors I, Quesada J, Lee JG-H, Yeh PJ. 2017. Space invaders: House Sparrow densities along three urban-agricultural landscapes. Avian Conservation and Ecology 12:11.

Perrins C, Cramp S. 1998. The complete birds of the Western Palearctic on CD-ROM. Oxford (UK): Oxford University Press.

Porter CK, Behl NJ. 2016. Predation and scavenging on other birds by Western Meadowlarks (Sturnella neglecta) during a spring snowstorm. Wilson Journal of Ornithology 128:664-667.

Selva N, Jędrzejewska B, Jędrzejewski W, Wajrak A. 2005. Factors affecting carcass use by a guild of scavengers in European temperate woodland. Canadian Journal of Zoology 83:1590-1601.

Sol D, González-Lagos C, Moreira D, Maspons J, Lapiedra O. 2014. Urbanisation tolerance and the loss of avian diversity. Ecology Letters 17:942-950.

Sukonkin A. 2009. Sparrows meat. In: Alex Sukonkin Photography [cited 3 Mar 2018]. https://yandex.ua/ collections/card/5b15b2a755854d2c6ee34518/

Summers-Smith D, Christie DA, Garcia EFJ. 2018. House Sparrow (Passer domesticus). In: del Hoyo J, Elliott A, Sargatal J, Christie DA, Kirwan G, editors. Handbook of the birds of the world Alive. Barcelona (Spain): Lynx Edicions [cited 6 Mar 2018]. https://www.hbw. com/species/house-sparrow-passer-domesticus

Vincent KE. 2005. Investigating the causes of the decline of the urban House Sparrow Passer domesticus population in Britain [dissertation]. Leicester, (UK): Montfort University.

Wilman H, Belmaker J, Simpson J, de la Rosa C, Rivadeneira MM, Jetz W. 2014. EltonTraits 1.0: Species-level foraging attributes of the world's birds and mammals. Ecology 95:2027. 
Copyright of Wilson Journal of Ornithology is the property of Wilson Ornithological Society and its content may not be copied or emailed to multiple sites or posted to a listserv without the copyright holder's express written permission. However, users may print, download, or email articles for individual use. 